\title{
TEMPERATURE MEASUREMENTS IN ATHABASCA GLACIER, ALBERTA, CANADA
}

\author{
By W. S. B. Paterson \\ (Polar Continental Shelf Project, Department of Energy, Mines and Resources, Ottawa, \\ Ontario, Canada)
}

\begin{abstract}
The temperature in the ablation area of Athabasca Glacier is about $-0.5^{\circ} \mathrm{C}$ at a depth of $10 \mathrm{~m}$. Below $17 \mathrm{~m}$ the temperature is slightly below the calculated pressure melting point (average difference $0.01 \mathrm{deg}$ ) in some places. Heat produced by ice deformation is calculated as a function of depth in two bore holes. Only in about the lower half of the glacier thickness is this heat sufficient to maintain the ice at the observed temperature as the hydrostatic pressure is reduced by ablation. Freezing of water within the ice must provide heat for this purpose elsewhere in the glacier; it must also provide heat to maintain the deeper ice close to the melting point even though the $10 \mathrm{~m}$ temperature is negative. The minimum water content needed is estimated to be between 0.5 and $1 \%$. It is argued that most of this water must be water trapped between grains when the ice formed from firn. The small difference from the pressure melting temperature measured below $17 \mathrm{~m}$ probably arises either from impurities or because, as a result of heat supplied for pressure-melting of ice around air bubbles, the ice is at the melting point corresponding to the
bubble pressure rather than to the hydrostatic pressure.
\end{abstract}

Resumé. Mesures de température dans le glacier de l'Athabasca, Alberta, Canada. La température dans la zone d'ablation du glacier de l'Athabasca est $c .-0,5{ }^{\circ} \mathrm{C}$ pour une profondeur de $10 \mathrm{~m}$. Au-dessous de $17 \mathrm{~m}$, la température se trouve quelquefois un peu au-dessous du point de fusion sous pression calculé (variation environ o,or deg). La chaleur produite par la déformation de la glace est calculée en fonction de la profondeur pour deux trous de forage. C'est seulement dans la moitié inférieure de la profondeur du glacier que cette chaleur suffit pour maintenir la glace à la température observée quand la pression hydrostatique diminue selon l'ablation. La congélation de l'eau dans la glace doit donner de la chaleur à cet effet dans d'autres endroits du glacier; il doit aussi produire de la chaleur pour maintenir la glace la plus basse aux approches du point de fusion, même avec une température négative à to $\mathrm{m}$. La teneur en eau nécessaire est estimée être environ au minimum entre 0,5 et $\mathrm{r} \%$. On met en avant que le plupart de cette eau doit être de l'eau renfermée entre les grains quand la glace se forme en névé. Le petit écart entre la température et le point de fusion sous pression enregistré au-dessous de $17 \mathrm{~m}$ s'explique probablement par la présence d'impuretés, ou bien, puisque la pression qui fait fondre la glace environnante des bulles de l'air consomme de la chaleur, par le fait que la glace atteint le point de fusion qui correspond à la pression de ces bulles plutôt qu'à la pression hydrostatique.

Zusammenfassung. Temperalurmessungen im Athabasca Glacier, Alberta, Kanada. Die Temperatur im Ablationsgebiet des Athabasca Glacier beträgt in $10 \mathrm{~m}$ Tiefe etwa $-0,5{ }^{\circ} \mathrm{C}$. Unterhalb $17 \mathrm{~m} \mathrm{liegt} \mathrm{die}$ Temperatur an einigen Stellen knapp unter dem errechneten Druckschmelzpunkt (mittlere Differenz o,o $^{\circ}{ }^{\circ}$ ). Die durch Eisdeformation erzeugte Wärme wird als Funktion der Tiefe in zwei Bohrlöchern berechnet. Nur für etwa die untere Hälfte der Gletscherdicke reicht diese Wärme zur Erhaltung der beobachteten Eistemperatur aus, da der hydrostatische Druck durch die Ablation vermindert wird. Gefrieren von Wasser im Eis muss die dafür notwendige Wärme an anderer Stelle im Gletscher freisetzen; es muss auch Wärme liefern, um das tiefere Eis nahe am Schmelzpunkt zu halten, auch wenn die ro m-Temperatur negativ ist. Der minimal notwendige Wassergehalt wird auf $0,5^{-1} \%$ geschätzt. Es wird geschlossen, dass der grösste Teil davon Wasser sein muss, das bei der Bildung des Eises aus Firn zwischen den Körnern eingeschlossen wurde. Die geringe Differenz zur Druckschmelztemperatur, die unterhalb $17 \mathrm{~m}$ gemessen wurde, stammt wahrscheinlich entweder von Verunreinigungen oder daher, dass sich das Eis - als Wirkung der durch das Schmelzen von Eis um Luftblasen freiwerdenden Wärme - an jenem Schmelzpunkt befindet, der dem Blasendruck entspricht, nicht aber dem hydrostatischen Druck.

\section{Introduction}

Athabasca Glacier in the Canadian Rocky Mountains has been the scene of studies of glacier flow (Savage and Paterson, r963, r965; Paterson and Savage r963[a], [b]; Paterson, I964, I970; Raymond and Kamb, I968; Raymond, unpublished), seismic investigations (Clee and others, I969; Neave and Savage, 1970), and measurements of electrical properties of glacier ice (Watt and Maxwell, ig6o; Keller and Frischknecht, 1960, I96r). Interpretation of these studies requires knowledge of whether the ice is at the pressure melting point; difficulties in thermal drilling suggested that it might not be (Savage and Paterson, r963). Some temperature measurements have now been made; they are discussed in this paper. 


\section{Techniques}

Ten-meter temperatures were measured, within a few days of completion of drilling, in bore holes made with a hand drill. Electrically powered thermal drills were used for bore holes deeper than ro $\mathrm{m}$. Except in one case, a multicore cable containing pairs of thermistors at intervals was attached to the power cable and descended into the ice with it. On completion of drilling, the thermistor cable, power cable and drill all remained in the hole. In the exceptional case, the thermistor cable was placed in the hole after the drill had been withdrawn. Temperatures were measured at intervals over periods of up to 3 years. Figure I shows locations of bore holes, each designated by its depth in meters. With reference to

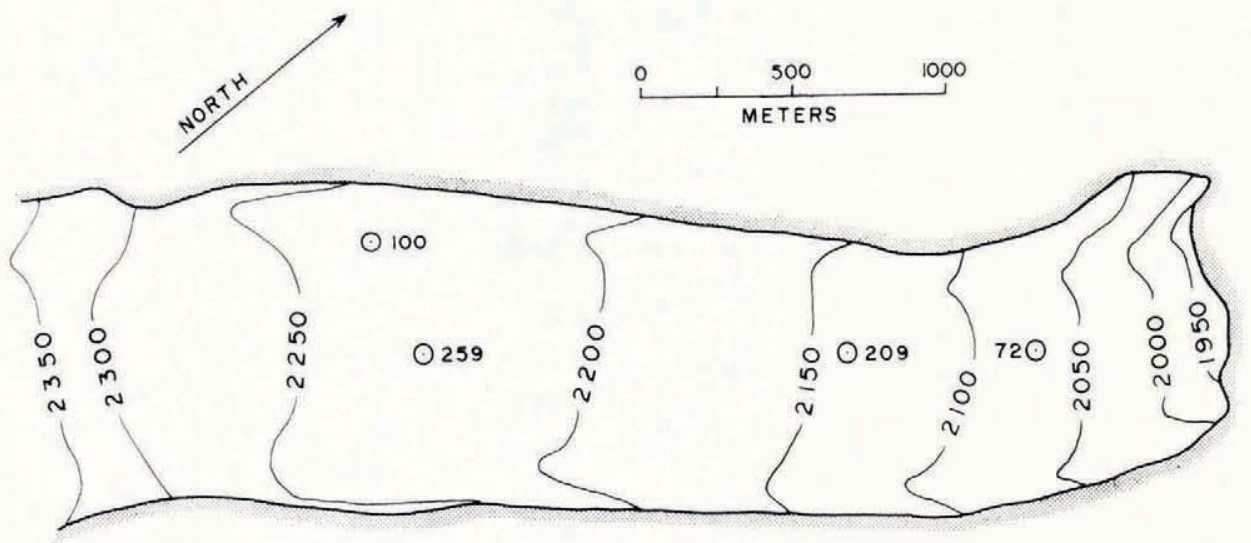

Fig. I. Map of lower part of Athabasca Glacier with locations of bore holes used in the present study. Each bore hole is designated by its depth in meters. Contour elevations are in meters above sea-level.

previous flow studies (Paterson and Savage, I963), hole 259 was roo $\mathrm{m}$ down glacier from the 1960 position of hole 322 , hole 209 was close to the 1960 position of the old hole 209 and hole 72 was close to the 1960 position of stake L 34 . Hole roo was hole 4 a of Raymond (unpublished). Table I contains information about the bore holes. Measurements were made only in some holes in April and June 1967; the other cables could not be found beneath the snow because the stakes marking them had broken. Holes 259 and 209 had to be abandoned when the cables broke, in hole 259 this happened before any measurements had been made. Measurements in the other holes were discontinued when sufficient data had been obtained.

As the holes contained water when they were drilled, we must discuss whether subsequent temperature measurements are reliable. Because the water level in a bore hole varied and because, occasionally, the drill appeared to penetrate water-filled cavities in the ice, the bore holes seemed to be connected to a "water table" in the glacier. In summer, the water table

TABLE I. BORE-HOLE INFORMATION

$\begin{array}{llrrrr}\text { Designation of hole (= depth) } & \mathrm{m} & 259 & 209 & 72 & \text { 100 } \\ \text { Ice thickness } & \mathrm{m} & 325 & 209 & 113 & 260 \\ \text { Depth of lowest thermistor } & \mathrm{m} & 257 & 198 & 54 & 55 \\ \text { Number of thermistors } & & 14 & 14 & 6 & 6 \\ \text { Date of cable installation } & & 7 / 66 & 8 / 66 & 8 / 66 & 8 / 67 \\ \text { Dates of measurements } & - & 4 / 67 & 6 / 67 & 8 / 68 \\ & & 6 / 67 & 8 / 67 & 8 / 69 \\ & & & 8 / 68 & \end{array}$


is near the surface but, when the supply of surface melt water is cut off at the end of summer, the water table probably falls to near the base of the glacier. Previous experiences with cased bore holes provide some evidence for this. After the winter, the casings were almost always blocked by ice near the surface. After this ice had been penetrated, the casing was usually found to be free of ice until near the bottom, where further ice plugs were encountered. The lower plugs probably indicate the position of the water table in winter. Shreve and Sharp (1970), who observed the same phenomenon on Blue Glacier, have discussed it in detail. Once the water drains out of a bore hole, ice flow will begin to close it and eventually the thermistor cable will be gripped by the ice. There is some evidence for this: the cables could not be moved in the holes after the first summer and, in addition, some of the cables broke. For example, in April 1967 the cable in hole 209 was intact, by June it had broken somewhere between 154 and I $99 \mathrm{~m}$, by August it had broken again between 39 and $62 \mathrm{~m}$, and by the following August it had broken above $39 \mathrm{~m}$. Such behaviour strongly suggests that the cable was firmly fixed in the ice. That the cables in holes 72 and 100 have not broken yet can be attributed to the stronger type of cable used there.

The strongest evidence that the cables were firmly embedded in the ice, not in a waterfilled bore hole, is the fact that, although measurements were made in more than one year and at different times of year, at no point did the measured temperature ever change. Also, apart from two exceptions to be discussed later, all temperatures were below the $0^{\circ} \mathrm{C}$ measured at all depths at the time of drilling. Again, two thermistors, originally at a depth of $9 \mathrm{~m}$ in hole 72 , gave readings in the range -0.2 to $-0.5{ }^{\circ} \mathrm{C}$ at different times before they melted out 3 years later; thus these thermistors were in ice, not in a water-filled hole.

Another possible source of error is that the water originally in each bore hole perturbs the temperature of the surrounding ice. Bullard (1947) has studied a similar problem. Calculations based on his formula show that, if the hole were full of water for 3 months, the temperature disturbance would be reduced to $5 \%$ of its initial value 5 months after the water drained.

The mean difference between the readings of the two thermistors at each depth, 0.03 deg for hole 209 and 0.02 deg for the other holes, has been taken as the standard error of the measured temperature.

\section{Measured temperatures}

The average temperature at a depth of $10 \mathrm{~m}$ in the ablation area is $-0.5^{\circ} \mathrm{C}$. These measurements will be discussed separately (Paterson, in preparation). Figure 2 shows measured temperatures below $10 \mathrm{~m}$ and the pressure melting temperature at each depth, calculated using a gradient of $0.0074^{2} \mathrm{deg}$ bar $^{-1}$ equivalent to $6.62 \times 10^{-4}$ deg per $\mathrm{m}$ of ice (density $0.9 \mathrm{I} \mathrm{Mg} \mathrm{m}^{-3}$ ). Two thermistors (one at $24 \mathrm{~m}$ and one at $39 \mathrm{~m}$ ) indicate temperatures of $0^{\circ} \mathrm{C}$ although the other thermistors at the same depths do not. The suggested explanation is that the resistances of these two thermistors had changed slightly since calibration. These anomalous values were included in the statistical analysis.

For analysis, the data were divided into two parts; measurements above $70 \mathrm{~m}$ ( 3 bore holes) and measurements below $70 \mathrm{~m}$ (hole 209 only). Above $70 \mathrm{~m}$, data from the three bore holes appear consistent with each other and 12 of the 16 points lie to the left of the pressure melting line. The probability of this, or a more extreme, distribution occurring if the temperatures were equal to the pressure melting value, is only $4 \%$. The $t$-test confirms this result; the temperatures above $70 \mathrm{~m}$ are significantly (at the $5 \%$ level) below the pressure melting point, although the mean difference is only o.or deg. Similar tests show that the temperatures below $70 \mathrm{~m}$ do not differ significantly from the pressure melting point. An alternative way of subdividing the data is to separate the measurements in hole 209 from those in the other holes. Statistical tests then show that the temperatures in holes 72 and 


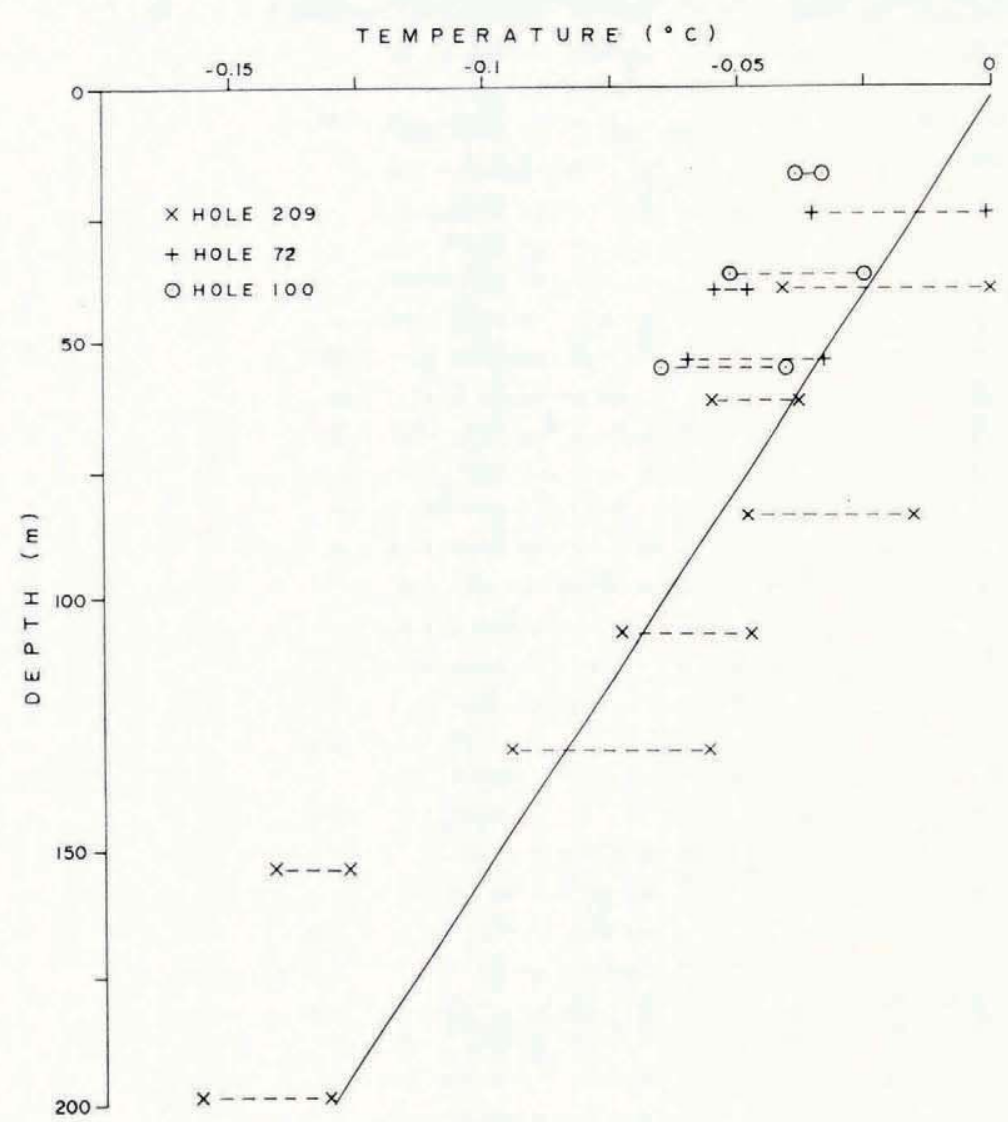

Fig. 2. Measured temperatures in Athabasca Glacier. The broken lines join the readings of the two thermistors at each depth. The solid line indicates the pressure melting point.

I 00 are significantly below the pressure melting point, whereas those in hole 209 are not, except for the point at $\mathrm{I} 54 \mathrm{~m}$ where the discrepancy is larger than can reasonably be attributed to experimental inaccuracies. As holes 209 and 72 are both on the center line of the glacier and only about $65^{\circ} \mathrm{m}$ apart, one would not expect their thermal regimes to differ. Moreover, as regards distance along the glacier, hole 209 lies between the other two holes. For these reasons, I think that the difference in temperature conditions is probably a function of depth rather than position. However, the data are inadequate to establish this conclusively.

\section{EXPECTED TEMPERATURES}

For the moment we ignore the very small deviations from the pressure melting point at depths between 17 and $70 \mathrm{~m}$ and consider another problem. Larger deviations were expected, for three reasons that we now discuss.

Freezing in bore holes. Savage and Paterson (1963) have described cases of this. (i) One bore hole was blocked by ice that formed within the casing less than $5 \mathrm{~d}$ after completion of drilling. (ii) Each summer a thermal drill had to be used to remove ice plugs formed in the casings during the previous winter. During this operation there was a continuous hazard of ice reforming above the drill. Three bore holes were permanently blocked in this way. 
(iii) One bore hole was permanently blocked when ice formed above an acid bottle used for measurements of inclination. All these blockages were at depths well below the ro $\mathrm{m}$ cold layer at the surface. This suggested that temperatures at depth were at least one or two degrees below the pressure melting point. As this is not the case, the refreezing must have resulted from contamination by antifreeze as described by Shreve and Sharp (1970). Briefly, antifreeze placed in the casing leaks through the joints into the surrounding ice. Some melting occurs and the temperature drops. This causes the solution inside the casing to freeze, because the leakage has reduced the concentration of antifreeze there.

Heat conduction to the surface. The heat balance at the surface appears to be such that the Io $\mathrm{m}$ temperature is maintained at about $-0.5^{\circ} \mathrm{C}$. Thus temperatures would be expected to be below the pressure melting point for some distance below $10 \mathrm{~m}$. To calculate the magnitude of this effect, consider heat conduction in a semi-infinite medium, moving with velocity $v$ (negative and equal to the ablation rate of $\left.3.8 \mathrm{~m} \mathrm{a}^{-1}\right)$, with temperature $T_{0}\left(=0^{\circ} \mathrm{C}\right.$ ) at time $t=0$, and the surface maintained at $T_{1}\left(=-0.5^{\circ} \mathrm{C}\right)$ for $t>0$. Depth below Io $\mathrm{m}$ is denoted by $y$ and thermal diffusivity by $k$.

In the following analysis $k$ is assumed constant. However, as a result of impurities, glacier ice contains pockets of water. Thus any temperature change involves a phase change of some water or ice. It follows that impure ice has a higher specific heat than pure ice; the difference can be large near the melting point. Thermal conductivity also varies with temperature though to a lesser extent. Thus, in ice near the melting point, $k$ is a function of temperature. Calculations, based on formulae given by Schwerdtfeger $(1963)$ and on a salinity of $10^{-6}$, a reasonable value for glacier ice (Langway, 1967, p. 46 ), show that at $-0.5^{\circ} \mathrm{C}$ and below $k$ has the same value as for pure ice, at $-0.1^{\circ} \mathrm{C}$ the value is halved, while at $-0.0 \mathrm{I}^{\circ} \mathrm{C}$ the value is only about one hundredth that of pure ice. Because this effect has been ignored the following calculation is only approximate.

The equation of heat transfer is

$$
\partial T / \hat{c} t=k \partial^{2} T / \partial y^{2}-v \partial T / \partial y .
$$

Carslaw and Jaeger (1959, p. 388) give the solution

Here

$$
T=\frac{1}{2} T_{1}\left(\operatorname{erfc} \omega+\exp y^{\prime} \operatorname{erfc} \omega^{\prime}\right) .
$$

$$
\begin{aligned}
\omega & =\frac{1}{2}(y-v t)(k t)^{-\frac{1}{2},} \\
\omega^{\prime} & =\frac{1}{2}(y+v t)(k t)^{-\frac{1}{2},} \\
y^{\prime} & =v y / k, \\
\operatorname{erfc} \omega & =2 \pi^{-\frac{t}{t}} \int_{\omega}^{\infty} \exp \left(-z^{2}\right) \mathrm{d} z .
\end{aligned}
$$

For large values of $t$, the solution tends to a steady-state solution which, since $v$ is negative, is

$$
\tau=T_{\mathrm{I}} \exp y^{\prime} \text {. }
$$

Calculations show that, for $t \geqslant$ Io a, temperatures are within o.or deg of the steady-state value. On the assumption that the annual heat balance at the surface has not shown any significant trend in the past ro years, we adopt the steady-state solution, shown in Figure 3 .

Comparison of Figures 2 and 3 shows that the temperatures measured between $\mathrm{I} 7$ and about $30 \mathrm{~m}$ are higher than expected. Thus there must be a heat source in the ice.

Reduction of pressure melting point. As ice flows towards the surface, where it is removed by ablation, the hydrostatic pressure on any element of ice is progressively reduced and so its pressure melting temperature rises. Thus the ice in the ablation area should be below the pressure melting point unless there is a heat source within the glacier. It has long been recognized that, for a glacier to be temperate, there must be heat sources and sinks within 


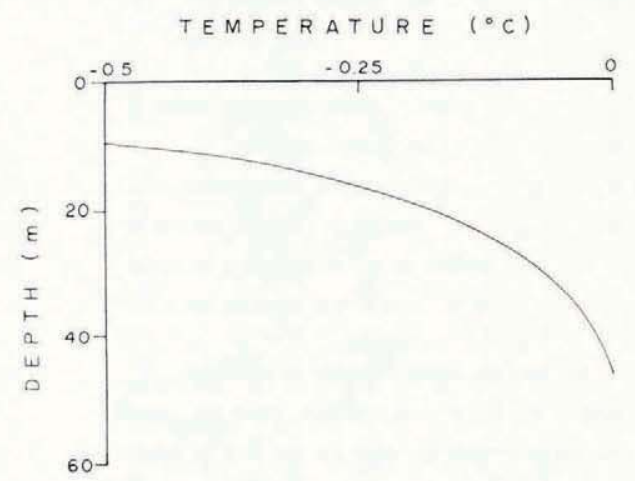

Fig. 3. Steady-state temperatures, calculated from Equation (3), on the assumption that the $10 \mathrm{~m}$ temperature remains at $-0.5^{\circ} \mathrm{C}$ throughout the year.

the ice. If $H$ is the amount of heat required annually to maintain unit volume of ice at depth $y$ at the pressure melting point

$$
H=-\rho c \lambda v .
$$

Here $\rho$ is the density of ice, $c$ its specific heat, $\lambda$ is the decrease in pressure melting point per unit decrease in distance below the ice surface, and $v(y)$ is the velocity component normal to the ice surface. Substitution of numerical values gives

$$
H / v=-\mathrm{I} 255 \mathrm{~J} \mathrm{~m}^{-4} \text {. }
$$

For consistency with the observation that the longitudinal strain-rate varies linearly with depth and with the fact that ice is incompressible, we should take $v$ to be a quadratic function of $y$. However, for present purposes it is sufficiently accurate to use the linear relation

$$
v=v_{\mathrm{s}}(\mathrm{s}-y / h) \text {. }
$$

Here $v_{\mathrm{s}}$ is the value of $v$ at the surface (the ablation rate) and $h$ is the ice thickness. The broken lines in Figure 4 show $H$ as a function of depth for holes 322 and 209. We next consider possible sources of this heat.

\section{Heat sources within the glacier}

Any heating of the interior of the glacier must be by heat generated within it. At the base, geothermal heat and heat produced by sliding cannot be conducted into the glacier because the temperature gradient (the pressure-melting gradient) is in the wrong direction. Moreover, the fact that the ro $\mathrm{m}$ temperature is negative indicates a net loss of heat at the surface. There are two heat sources in the glacier: heat of strain-work and latent heat released when water within the ice freezes.

Strain-work. The amount of heat can be calculated from the bore hole measurements of Savage and Paterson ( 1963$)$. The formula is

$$
W=\dot{\epsilon}_{x} \sigma_{x}+\dot{\epsilon}_{y} \sigma_{y}+\dot{\epsilon}_{z} \sigma_{z}+2 \dot{\epsilon}_{x y} \tau_{x y}+2 \dot{\epsilon}_{y z} \tau_{y z}+2 \dot{\epsilon}_{z x} \tau_{z x}
$$

Here $W$ is heat per unit volume per unit time, the $\dot{\epsilon}$ are strain-rates and the $\sigma$ and $\tau$ are stresses. The shear strain-rates are defined by $\dot{\epsilon}_{x y}=\frac{1}{2}(\partial u / \partial y+\partial v / \partial x)$ and similar relations, where $u, v$ are velocity components. On the center line of the glacier, the relation reduces to

$$
W=2\left(\dot{\epsilon}_{x} \sigma_{x}{ }^{\prime}+\dot{\epsilon}_{x y} \tau_{x y}\right)
$$

Here the $x$ coordinate is measured along the center line, the $y$ coordinate is measured perpendicular to the glacier surface positive downwards and $\sigma_{x}^{\prime}$ is the longitudinal stress deviator. 


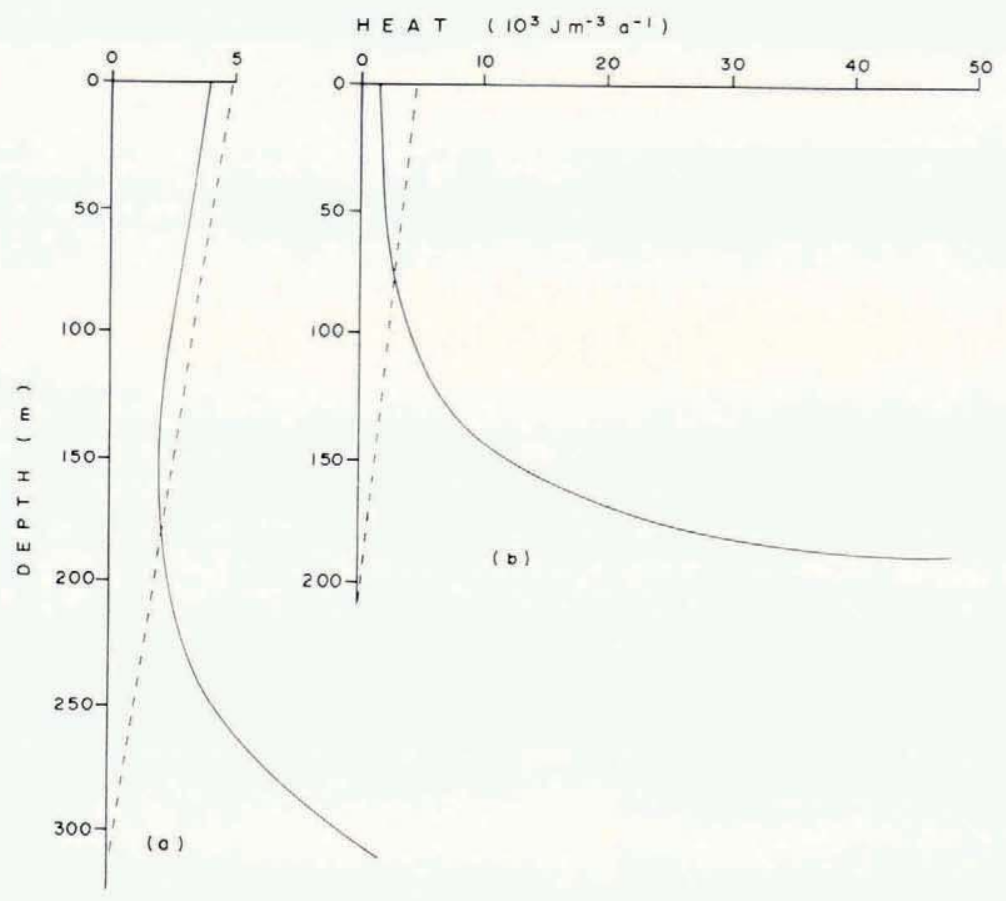

Fig. 4. Solid lines: heat produced by ice deformation. Broken lines: heat required to maintain ice at pressure melting point as hydrostatic pressure is reduced by ice flow towards the surface. Data for $(a)$ hole 322 and $(b)$ hole 209 of Savage and Paterson $(1963)$.

The values of $\dot{\epsilon}_{x}, \dot{\epsilon}_{x y}, \tau_{x y}$ were calculated as described in previous papers (Savage and Paterson, I963; Paterson and Savage, I963[b]; $\dot{\epsilon}_{x}$ was taken to vary linearly with depth as it has been shown to do (Savage and Paterson, I963). Values of $\sigma_{x}^{\prime}$ were calculated from $\dot{\epsilon}_{x}$ and the flow law of ice, with values of the constants derived from the bore-hole data.

Figure 4 shows $W$ as a function of depth in holes 322 and 209. The value is much smaller in hole 322 than in hole 209 because sliding accounts for about $75 \%$ of the glacier movement at hole 322 but for only about $10 \%$ at hole 209. Also shown in Figure 4 is $H$, the heat needed to maintain the ice at the pressure melting point, discussed in the preceding section. In each case, strain-work provides enough heat only in about the lower half of the ice. Above this level, heat must be supplied by the refreezing of water already present within the glacier. Figure 4 also shows that, throughout most of the lower half, strain-work produces more than enough heat to maintain the ice at the pressure melting point. As the temperature gradient in the ice is linear (the pressure melting gradient), this surplus heat cannot be conducted upwards or downwards; it must melt ice where it is generated. The amount melted is very small however; the heat generated at a depth of $190 \mathrm{~m}$ in hole 209 would melt about $1.5 \%$ of the ice in roo a.

Water within the glacier. We have shown that a heat source is necessary to maintain temperatures at $17 \mathrm{~m}$ and below within o.or deg of the pressure melting point, in spite of the fact that the surface energy balance is such as to maintain the $10-$ meter temperature at $-0.5^{\circ} \mathrm{C}$. As strain-work cannot supply this heat, it must be produced by continuous freezing of water in the ice. Thus, between ro and $17 \mathrm{~m}$, there must be an interface below which the ice contains water but above which it does not. Indirect evidence for this comes from the following observation of Raymond (personal communication): "In a given bore hole (in 
Athabasca Glacier), the near-surface zone, where short-time-scale refreezing occurred, seemed to have a sharp bottom ... typically around 12 to $13 \mathrm{~m}$ ".

We can estimate the amount of water from the position of the interface in the following way. Let the water content, by volume, below the interface be $f$, assumed to be constant. Let $y$ denote depth below the initial ro m level. At time $t$, the $\mathrm{Io} \mathrm{m}$ level will be at $y=v_{\mathrm{s}} t$ where $v_{\mathrm{s}}$ is the ablation rate, taken positive. Let $T(y, t)$ denote temperature. We suppose that $T\left(v_{\mathrm{s}} t, t\right)=\mathcal{T}_{0}$, a constant. Let $Y(t)$ be the $y$ coordinate of the interface. At the interface, the rate of production of latent heat equals the rate at which heat is conducted upwards. Thus, at $y=r$,

$$
f L \rho \mathrm{d} Y / \mathrm{d} t=-K \partial T / \partial y .
$$

Here $L$ is the latent heat of fusion of ice, $\rho$ the density, and $K$ the thermal conductivity. We now make the simplifying assumption that, at all times, the temperature gradient in the ice above the interface is linear. Thus $\partial T / \partial y=T_{0}\left(Y-v_{\mathrm{s}} t\right)^{-1}$. If $\mathrm{d} Y / \mathrm{d} t$ were to increase, the temperature gradient above the interface would be reduced, less heat would be carried away and so the rate of freezing of water, and therefore $\mathrm{d} Y / \mathrm{d} t$, would be reduced. We therefore expect a steady state to be set up such that $\mathrm{d} r / \mathrm{d} t=v_{\mathrm{s}}$. If $Y^{\prime}$ is the steady state value of $r-v_{\mathrm{s}} t$, we have $\partial T / \partial y=T_{\mathrm{o}} / Y^{\prime}$ and so

$$
r^{\prime}=-K T_{\mathrm{o}} / f L \rho v_{\mathrm{s}} .
$$

With $T_{0}=-0.5{ }^{\circ} \mathrm{C}, v_{\mathrm{s}}=3.8 \mathrm{~m} \mathrm{a}^{-1}$, and appropriate values for the other constants, we have

$$
r^{\prime}=0.03 f^{-1} \mathrm{~m}
$$

which gives the values in Table II.

$$
\begin{aligned}
& \text { TABle II. LEVEL OF WATER IN A GLACIER FOR } \\
& \text { VARIOUS WATER CONTENTS } \\
& f_{Y^{\prime} \mathrm{m}} \\
& \begin{array}{cccc} 
& 0.01 & 0.005 & 0.001 \\
& 3 & 6 & 30
\end{array}
\end{aligned}
$$

On the assumption that our observations correspond to such a steady state, the fact that $r^{\prime}<7 \mathrm{~m}$ indicates that the water content of the ice is about 0.5 or $\mathrm{I} \%$.

\section{Origin of WAter Within the Glacier}

We are concerned here solely with the water dispersed in the tiny channels and cavities between the ice grains. In addition, the glacier contains water in crevasses, moulins, stream channels and large isolated cavities. These undoubtedly influence the ice temperature in their vicinity but there are not enough of them to affect more than a small part of the whole glacier.

Water in the glacier might originate in at least five ways: by percolation from the surface, by strain-work, by melting induced by changes in hydrostatic pressure, by being trapped in small pockets when the ice formed from firn, and by a mechanism proposed by Bader. In discussing these mechanisms we do not mean to imply that all the water necessarily originates in the same way.

Percolation of melt water from the surface is apparently excluded, except near moulins and crevasses, by the cold layer that persists at a depth of about $10 \mathrm{~m}$ throughout the ablation season. The mechanism of Bader (1950) can also be excluded. He postulated that, as ice flows towards the surface in the ablation area, the pressure in air bubbles is kept approximately equal to the hydrostatic pressure in the surrounding ice by pressure melting of ice arouncl each bubble. Because the water occupies less volume than the ice occupied, the air 
can expand. Bader measured the air content of four surface ice samples from Malaspina Glacier and, on the basis of his postulate, calculated the water content. He obtained values up to $28 \%$; these are unreasonably high. Moreover, there is no source of heat adequate to produce such amounts of water.

The heat of strain-work melts some ice. As previously stated, the deformation (mainly shear) near the bottom of hole $209\left(\dot{\epsilon}_{x y}=0.2 \mathrm{a}^{-1}, \tau_{x y}=1.2\right.$ bar $)$ produces enough heat to melt $1.5 \%$ of the ice in Ioo a. Near the valley walls, the value of the transverse shear is probably about the same as this. To melt this quantity of ice outside the marginal and basal zones of the glacier would require longitudinal stresses of these magnitudes. In Athabasca Glacier, longitudinal strain-rates of $0.2 \mathrm{a}^{-1}$ or more are encountered only in the ice falls and the ice travels through them in very much less than roo a. We conclude that, though the heat of deformation produces some water, it cannot produce concentrations of the order of I \% throughout the ice.

Some water will also be produced by the reverse process to one considered previously. As an element of ice is progressively buried in the accumulation area, the hydrostatic pressure increases, the pressure melting temperature is lowered and some ice will melt. The broken curves in Figure 4 can be taken to indicate the amount of heat involved if the values shown are divided by about 4, because the accumulation rate in Athabasca Glacier is roughly I $\mathrm{m} \mathrm{a}^{-1}$ compared with the ablation rate of $3.8 \mathrm{~m} \mathrm{a}^{-1}$. The amount of heat is much smaller than the heat of deformation near the bottom of hole 209. As ice probably takes, at most, a few hundred years to travel through the accumulation area, we conclude that this process cannot produce a water concentration of the order of $1 \%$. This process will also operate in the ablation area in the region immediately below the icefalls where the ice thickens rapidly in the down-glacier direction. In this region, the velocity vectors at depth will be inclined downwards relative to the ice surface. However, the ice travels through this region in a few years. Moreover, the velocity vectors in the near-surface layers will still be inclined upwards relative to the surface, to compensate for ablation; thus no water will be formed in these layers.

Thus we are left with the last explanation namely that most of the water in the ablation area is water trapped during the transformation of firn to ice in the accumulation area. A corollary is that glacier ice is impermeable to water. Joubert (1963) has determined the water content of ice at depths between 35 and $60 \mathrm{~m}$ in the accumulation area of the Mer de Glace. The measured concentrations $(0.15$ to $\mathrm{I} \%$ ) are about the same as those required to explain the temperature measurements in Athabasca Glacier. Joubert's observation that water content varied periodically with depth, with layers of maximum water content 3 or $4 \mathrm{~m}$ apart, appears to support the view that glacier ice is impermeable, otherwise such fluctuations should be smoothed out. On the other hand, Nye and Frank (in press) believe that ice at the melting point is permeable to water.

\section{Temperatures below pressure melting point}

It remains to discuss why some temperatures are, on the average, about o.or deg below the calculated pressure melting point. Two possible explanations have already been mentioned, others relate to impurities in the ice, curvature of ice--water interfaces, and the effect of air bubbles.

One possibility is that the bore holes had not closed around the thermistor cables but still contained water. In this case the density of water, not ice, should be used in calculating the pressure melting temperature. This would explain the observed discrepancy. However we do not think that the bore holes contained water, for the reasons discussed in section 2.

Another possible explanation is the fact that, throughout half of the ice thickness, strainwork does not provide enough heat to maintain the ice at the pressure melting point as the 
hydrostatic pressure is reduced. However, we have shown that there must be water in the ice to provide latent heat to maintain the ice close to the pressure melting point in spite of heat loss at the surface. This water should be sufficient to provide the small amount of additional heat needed to compensate for the reduction in hydrostatic pressure.

Langway ( 1967 , p. 46) has summarized available data on the chemical composition of glacier ice. For glaciers in temperate regions, the total salt content (by weight) was found to be about 1 part in $10^{6}$ in Austria and about one tenth of this value in Norway. Glacier ice at the melting point consists of crystals of pure ice surrounded by films of brine (Quincke, r905; Renaud, 1949). Thus for ice with a water content of I per cent and measured salt content of $\mathrm{I}$ in $1^{1} \mathrm{O}^{6}$, the effective salt content is $\mathrm{I}$ in $\mathrm{IO}^{4}$. From the linear relation between freezing point and salinity given by Pounder ( 1965, p. 4) we deduce that the above salt content would lower the melting point by about $0.005 \mathrm{deg}$. Thus the presence of impurities might perhaps explain the observed temperatures.

Under a pressure of $1.013 \mathrm{bar}$, ice and water are in equilibrium at $273.15 \mathrm{~K}$ only if the interface is plane. Williams ( 1968, p. $4 \mathrm{I}$ ) gives the following formula for $\Delta T$, the change in equilibrium temperature, when the radius of curvature of the ice-water interface is $r$ :

$$
\Delta T / T=-2 V \gamma / L r .
$$

Here $T=273.15 \mathrm{~K}, V$ is the specific volume of water, $\gamma$ is the surface free energy of the ice-water interface, and $L$ is the latent heat of fusion of ice. Substitution of numerical values gives

$$
r \Delta T=5 \times 10^{-5} \mathrm{~mm} \mathrm{deg} .
$$

Thus, for $\Delta T=0.01 \mathrm{deg}, r=5 \times 1 \mathrm{O}^{-3} \mathrm{~mm}$. The relevant radius of curvature is that of the ice-water interface at a water vein lying at a three-gain intersection. As this radius of curvature might perhaps be as small as $5 \times \mathrm{IO}^{-3} \mathrm{~mm}$, this explanation cannot be completely dismissed. However, the estimated water content of $\mathrm{I} \%$ could hardly be contained in veins of this size.

The explanation in terms of air bubbles is related to Bader's hypothesis, already discussed. As ice flows towards the surface, pressure melting will occur round air bubbles with heat supplied by the surrounding ice. Because there is not enough heat to maintain the bubble pressure at the hydrostatic pressure, the ice will be at the melting temperature corresponding to the bubble pressure not to the hydrostatic pressure of the surrounding ice. We suggest that this is the most likely explanation of the measured temperatures. The observed difference, o.or deg, corresponds to a pressure difference of $\mathrm{I} .5$ bar. This is a reasonable value. Bader ( $\left.195^{\circ}\right)$ measured bubble pressures of $\mathrm{I}$ to 2 bar in ice at the surface of Malaspina Glacier. Coachman and others (1956) measured bubble pressures of $\mathrm{I}$ to 3 bar in surface samples from Stor Glaciären. That the difference may not extend below $70 \mathrm{~m}$ can perhaps be explained by the fact that the rate of change of hydrostatic pressure varies inversely with depth. The greater the depth, the more time there is for the bubbles to reach equilibrium with the hydrostatic pressure, partly by Bader's mechanism and also by plastic flow of the ice around each bubble. As there may be slight differences in pressure between bubbles at the same depth, there may also be small inhomogeneities in temperature. A non-uniform distribution of impurities could also produce such inhomogeneities.

\section{Acknowledgements}

Dr C. F. Raymond generously donated one bore hole. The other holes were made with thermal drills designed by Dr J. C. Savage and manufactured at the University of Toronto. Dr J. C. Savage and Dr G. K. C. Clarke, and Messrs K. G. Neave and R. Sherwood assisted in various phases of the field work. Mr W. Ruddy of Snowmobile Tours Ltd., Jasper, Alberta, 
generously provided snowmobile time to transport equipment on the glacier and assisted in other ways. Dr J. F. Nye, Dr J. C. Savage and a referee made valuable comments on the paper.

MS. received 22 December 1970 and in revised form 26 April 1970

\section{REFERENCES}

Bader, H. 1950. The significance of air bubbles in glacier ice. Fournal of Glaciology, Vol. 1, No. 8, p. 443-51.

Bullard, E. C. 1947. The time necessary for a borehole to attain temperature equilibrium. Monthly Notices of the Royal Astronomical Society. Geophysical Supplement, Vol. 5, No. 5, p. 127-30.

Carslaw, H. S., and Jaeger, J. C. 1959. Conduction of heat in solids. Second edition. Oxford, Clarendon Press.

Clee, T. E., and others. 1969 . Internal friction in ice near its melting point, [by] T. E. Clee, J. C. Savage and K. G. Neave. Journal of Geophysical Research, Vol. 74, No. 4, p. 973-80.

Coachman, L. K., and others. 1956. Gas enclosures in a temperate glacier, by L. K. Coachman, E. Hemmingsen and P. F. Scholander. Tellus, Vol. 8, No. 4, p. 415-23.

Joubert, J.-L. I963. Stratigraphie de la glace tempérée à l'aide de la teneur en eau liquide. Comptes Rendus Hebdomadaires des Séances de l'Académie des Sciences (Paris), Tom. 257, No. 23, p. 3638-39.

Keller, G. V., and Frischknecht, F. C. 1960. Electrical resistivity studies on the Athabasca Glacier, Alberta, Canada. Fournal of Research of the National Bureau of Standards (Washington, D.C.), Sect D, Vol. 64, No. 5 , p. $439-48$.

Keller, G. V., and Frischknecht, F. C. 1961. Induction and galvanic resistivity studies on the Athabasca Glacier, Alberta, Canada. (In Raasch, G. O., ed. Geology of the Arctic: proceedings of the first international symposium on Arctic geology held in Calgary, Alberta, January $11-13,1960$. Toronto, University of Toronto Press, Vol. 2, p. $809-32$.

Langway, C. C., jr. 1967. Stratigraphic analysis of a deep ice core from Greenland. U.S. Cold Regions Research and Engineering Laboratory. Research Report 77.

Neave, K. G., and Savage, J. C. 1970. Icequakes on the Athabasca Glacier. Fournal of Geophysical Research, Vol. 75 , No. 8 , p. $135 \mathrm{I}-62$.

Nye, J. F., and Frank, F. C. In press. The hydrology of the intergranular veins in a temperate glacier. Union Géodésique et Géophysique Internationale. Association Internationale d'Hydrologie Scientifique. Commission de Neiges et Glaces. Symposium on the hydrology of glaciers, Cambridge, 7-13 September 1969, organized by the Glaciological Society.

Paterson, W. S. B. I 1964 . Variations in velocity of Athabasca Glacier with time. Fournal of Glaciology, Vol. 5 , No. 39 , p. $277-85$.

Paterson, W. S. B. 1970. The sliding velocity of Athabasca Glacier, Canada. Journal of Glaciology, Vol. 9, No. 55, p. $55-63$.

Paterson, W. S. B., and Savage, J. C. 1963 [a]. Geometry and movement of the Athabasca Glacier. Fournal of Geophysical Research, Vol. 68, No. 15, p. 4513-20.

Paterson, W. S. B., and Savage, J. C. ${ }_{1963}[\mathrm{~b}]$. Measurements on Athabasca Glacier relating to the flow law of ice. Journal of Geophysical Research, Vol. 68, No. ${ }^{1} 5$, p. $4537-43$.

Pounder, E. R. 1965. The physics of ice. Oxford, Pergamon Press. (The Commonwealth and International Library. Geophysics Division.)

Quincke, G. ${ }^{1} 905$. The formation of ice and the grained structure of glaciers. Nature, Vol. 72, No. 1874, p. 543-45.

Raymond, C. F. Unpublished. Flow in a transverse section of Athabasca Glacier, Alberta, Canada. [Ph.D. thesis, California Institute of Technology, 1969.]

Raymond, C. F., and Kamb, W. B. I968. Internal deformation over a transverse section of a valley glacier. Transactions. American Geophysical Union, Vol. 49, No. 1, p. 313. [Abstract.]

Renaud, A. I949. A contribution to the study of the glacier grain. Fournal of Glaciology, Vol, 1, No. 6, p. $320-24$.

Savage, J. C., and Paterson, W. S. B. 1963 . Borehole measurements in the Athabasca Glacier. Fournal of Geophysical Research, Vol. 68, No. I5, p. $45^{21-36 .}$

Savage, J. C., and Paterson, W. S. B. 1965. Additional borehole measurements in the Athabasca Glacier. Journal of Geophysical Research, Vol. 70, No. 14, p. $35^{11-1} 3$.

Schwerdtfeger, P. I 1963 . The thermal properties of sea ice. Fournal of Glaciology, Vol. 4, No. 36, p. $789-807$.

Shreve, R. L., and Sharp, R. P. I970. Internal deformation and thermal anomalies in lower Blue Glacier, Mount Olympus, Washington, U.S.A. Journal of Glaciology, Vol. 9, No. 55, p. 65-86.

Watt, A. D., and Maxwell, E. L. 1960. Measured electrical properties of snow and glacial ice. Journal of Research of the National Bureau of Standards (Washington, D.C.), Sect. D, Vol. 64, No. 4, p. 357-63.

Williams, P. J. 1968. Properties and behaviour of freezing soils. Canada. National Research Council. Division of Building Research. Research Paper No. 359. 